\title{
FAKTOR-FAKTOR YANG MEMPENGARUHI INVESTMENT OPPORTUNITY SET TERHADAP KEBIJAKAN HUTANG DAN FREE CASH FLOW
}

\section{FACTORS THAT INFLUENCE THE INVESTMENT OPPORTUNITY SET ON DEBT POLICY AND FREE CASH FLOW}

\author{
Tumpal Manik \\ Fakultas Ekonomi Universitas Maritim Raja Ali Haji (Tanjungpinang) \\ Email : tmanyk@gmail.com and tmanik@umrah.ac.id
}

\begin{abstract}
ABSTRAK
Penelitian ini bertujuan untuk menganalisis faktor-faktor yang mempengaruhi investment opportunity set terhadap kebijakan hutang dan free cash flow pada perusahaan manufaktur yang terdaftar di Bursa Efek Indonesia tahun 2016 - 2017. Pengambilan sampel dilakukan dengan metode purposive sampling. Jumlah populasi 168 yang memenuhi kriteria sebanyak 40 perusahaan, maka data penelitian $40 \times 2$ tahun yaitu 80 data. Pengolahan data penelitian untuk menguji hipotesis penelitian secara simultan dan parsial. Hasil penelitian bahawa faktor-faktor yang mempengaruhi investment opportunity set terhadap kebijakan hutang berpengaruh singnifikan, antara lain proksi ios berdasarkan Market to Book Value of Assets Ratio sebesar 16,1\%, Market to Book Value Equity Ratio sebesar 18,2\%, Earning per Share Price Ratio (sebesar 19,1\%, Capital Expenditure to Book Value Asset Ratio sebesar 17,6\%, Capital Expenditure to Market Value of Assets Ratio sebesar 15\%. Sedangkan investment opportunity set terhadap free cash flow berpengaruh signifikan.
\end{abstract}

Kata Kunci : Investment Opportunity Set, Kebijakan Hutang, Free Cash Flow

\section{ABSTRACT}

This study aims to analyze the factors that influence the investment opportunity set against debt policy and free cash flow in manufacturing companies listed on the Indonesia Stock Exchange in 2016 - 2017. Sampling is done by purposive sampling method. The population of 168 fulfills the criteria of 40 companies, so the $40 \times 2$ year research data is 80 data. Research data processing to test the research hypothesis simultaneously and partially. The results of the study that the factors that influence the investment opportunity set against debt policy have a significant effect, including IOS proxies based on Market to Book Value of Assets Ratio of 16.1\%, Market to Book Value Equity Ratio of $18.2 \%$, Earning per Share Price Ratio (amounting to 19.1\%, Capital Expenditure to Book Value Asset Ratio of 17.6\%, Capital Expenditure to Market Value of Assets Ratio of $15 \%$. While the investment opportunity set of free cash flow has a significant effect.

Keywords: Investment Opportunity Set, Debt Policy, Free Cash Flow

Hal. 1 


\section{PENDAHULUAN}

Mendorong kinerja perusahaan untuk meningkatkan hasil operasional kegiatan bisnis dapat dibuktikan dari laporan informasi bisnis usaha yakni perusahaan mengalami pertumbuhan nilai aset lancar dan aset tetap serta peningkatan laba dalam laporan keuangan. Perusahaan yang memiliki kinerja yang baik akan mampu mengembankan unit dan lini bisnis serta membayar kewajibannya serta. Namun sebaliknya pada perusahaan yang mengalami kinerja yang tidak baik akan menghadapi kesulitan cash flow operasional dan permasalahan keuangan sehingga membutuhkan tambahan investasi dana untuk pendanaan aktivitas bisnisnya melalui berbagai sumber pendanaan dari investor ekuitas dan kreditor di pasar modal, sehingga muncul kebijakan hutang.

Kebijakan hutang menjadi salah satu pilih para manajemen untuk menambah kas dan pendanaan operasional perusahaan, kebijakan hutang harus mampu meningkatkan kualtas laba pada periode akuntansi sehingga kalanjutan aktivitas bisnis perusahaan berjalan dengan baik, kebijakan hutang perusahaan juga berfungsi sebagai alat monitoring terhadap tindakan manajer yang dilakukan dalam pengelolaan perusahaan. Kebijakan hutang merupakan suatu kebijakan yang diambil oleh pihak manajemen dalam rangka memperoleh sumber pembiayaan bagi perusahaan sehingga dapat digunakan untuk membiayai aktivitas operasional perusahaan.

Kesempatan investasi perusahaan merupakan komponen penting bagi nilai pasar, sebab investasi sebagai salah satu indikator penting bagi perusahaan dalam meningkatkan nilai perusahaan yang menarik untuk dibahas. Kesempatan investasi seringkali sulit diprediksikan oleh para investor Karena aktivitas investasi dihadapkan pada berbagai macam risiko dan ketidakpastian. Informasi diperlukan oleh para investor untuk mengurangi kemungkinan risiko dan ketidakpastian dalam aktivitas investasi, sebab para investor hanya melihat sebatas laporan keuangan. Sedangkan laporan keuangan hanyalah informasi yang tercatat kadang tidak sesuai dengan nilai riil yang tersedia dalam perusahaan. Informasi tersebut diperoleh dengan melihat kinerja perusahaan yang umumnya tercermin dalam laporan keuangan.

Investment opportunity set (IOS) atau kesempatan investasi merupakan komponen penting bagi nilai pasar. Hal ini disebabkan Investment Opportunity Set (IOS) merupakan pilihan kesempatan investasi masa depan yang dapat mempengaruhi pertumbuhan aktiva perusahaan atauproyek yang memiliki net present value positif. Sehingga IOS memiliki perananyang sangat penting bagi perusahaan karena IOS merupakan keputusan investasi dalam bentuk kombinasi dari aktiva yang dimiliki dan opsi investasi di masa yang akan datang, dimana IOS tersebut akan mempengaruhi Kebijakan hutang dan Free cash flow merupakan kas perusahaan yang dapat di distribusikan kepada kreditur atau pemegang saham yang tidak diperlukan untuk modal kerja atau investasi pada aset.

Berdasarkan urian diatas, maka penulis tertarik untuk malakuan penelitian dengan judul Faktor-Faktor Yang Mempengaruhi Investment Opportunity Set Terhadap Kebijakan Hutang Dan Free Cash Flow pada perusahaan Manfaktur yang terdaftar di Bursa Efek Indonesia.

Penelitian ini bertujuan untuk menganalisis pengaruh Investment opportunity set (IOS) terhadap Kebijakan hutang dan Free cash flow. IOS melalui proksi IOS berbasis pada harga (Price Based Proxies); Market to Book Value Equity (MVE/BVE), Market to Book Value of Assets (MVA/BVA), Earning Per Share Price (EPS) dan Proksi berbasis pada investasi (InvestmentBased Proxies); Capital Expenditure to Book Value Asset (CEP/BVA), Capital Expenditure to Market Value of Assets (CEP/MVA). 


\section{LANDASAN TEORI}

\section{Investment Opportunity Set (IOS)}

Investment Opportunity Set (IOS) berhubungan dengan keputusan investasi dan pendanaan dalam perusahaam akan berdampak pada laporan ekonomi perusahaan serta kinerja perusahaan dalam jangka panjang, sebab tindakan keputusan investasi yang benar dan baik perlu dianalisis manajemen sesauai dengan kebijakan dan kemampuan perusahaan agar para manajemen tidak memiliki kebebasan dalam penggunaan kas perusahaan.

IOS memiliki peranan yang sangat penting bagi perusahaan karena IOS merupakan keputusan investasi dalam bentuk kombinasi dari aktiva yang dimiliki sebagai pilihan di masa yang akan datang, Investment Opportunity Set (IOS) merupakan pilihan kesempatan investasi masa depan yang dapat mempengaruhi pertumbuhan aset perusahaan serta proyek yang memiliki net present value positif, karena berdasarkan aktivitas Investment Opportunity Set (IOS) atau set kesempatan investasi komponen penting dari nilai pasar akan mempengaruhi cara pandang manajer, pemilik, investor dan kreditor terhadap perusahaan, sehingga dari IOS sebagai investasi yang diharapkan akan menghasilkan return yang lebih besar

Suartawan (2016), secara umum dapat disimpulkan bahwa IOS adalah hubungan antara pengeluaran saat ini maupun dimasa yang akan dating sebagai hasil dari keputusan investasi untuk menghasilkan nilai perusahaan. Perusahaan yang memiliki investment opportunity set tinggi menunjukkan bahwa perusahaan tersebut mempunyai kesempatan untuk bertumbuh sehingga manajer mempunyai kesempatan untuk berinvestasi. Ketika manajer dan investor memiliki informasi yang berbeda mengenai informasi internal perusahaan dimana dalam hal ini manajer lebih superior, maka manajer cenderung akan memainkan laba perusahaan untuk lebih memilih laba yang ditahan sebagai pendanaan investasi selanjutnya, karena manajer ingin mensejahterakan kepentingannya

Investment opportunity set menggambarkan tentang luasnya kesempatan atau peluang investasi bagi suatu perusahaan untuk kepentingan dimasa yang akan datang (Wulansari 2013). Perusahaan yang memiliki IOS tinggi cenderung dinilai positif oleh investor, maka calon investor akan tertarik untuk berinvestasi dengan harapan memperoleh return yang lebih besar dimasa yang akan datang. IOS merupakan pilihan kesempatan investasi masa depan yang dapat mempengaruhi pertumbuhan aktiva perusahaan atau proyek yang memiliki net present value positif (Anggia 2012), sesuai dengan pendapat Keown, et al. (2010), ketika peluang investasi perusahaan naik, rasio pembayaran dividen terpenuhi, melalui proksi IOS dari market value to book of asset ratio dianalisis berdasarkan harga.

Aharony (2010), mendefinisikan investasi sebagai komitmen saat ini dalam uang, untuk suatu periode waktu dengan tujuan untuk mendapatkan pembayaran di masa depan yang akan mengkompensasikan investor untuk: a) waktu ketika dana digunakan, b) tingkat inflasi yang diharapkan dan c) ketidakpastian atas pembayaran di masa depan. Untuk melakukan investasi, perusahaan membutuhkan kesempatan, suatu rencana atau proyek yang bisa dipilih untuk mewujudkan tujuannya untuk menghasilkan lebih banyak uang. Investasi secara umum adalah kegiatan menanamkan modal yang dilakukan oleh investor pada suatu aset tertentu untuk mendapatkan pengembalian yang lebih besar dibandingkan yang dikorbankan.

Kesempatan investasi (investment opportunity set) sebagai pilihan-pilihan investasi yang tersedia bagi individu atau perusahaan yang dapat dilakukankan perusahaan. Kesempatan investasi yang dimiliki perusahaan memengaruhi cara pandang manajer, pemilik, investor dan kreditor tentang nilai perusahaan.

Hal. 3 
Indah (2011), semakin tinggi market value to book of asset ratio maka semakin besar asset yang digunakan perusahaan dalam usahanya serta semakin besar kemungkinan perusahaan tersebut untuk bertumbuh. IOS dalam penelitian ini melalui Proksi IOS berbasis pada harga (Price-Based Proxies) : Market to Book Value Equity (MVE/BVE), Market to Book Value of Assets (MVA/BVA), Earning Per Share Price (EPS) dan Proksi IOS berbasis pada investasi (Investment-Based Proxies); Capital Expenditure to Book Value Asset (CEP/BVA), Capital Expenditure to Market Value of Assets (CEP/MVA).

\section{Kebijakan Hutang}

Hutang merupakan salah satu sumber pembiayaan eksternal yang digunakan oleh perusahaan untuk membiayai kebutuhan dananya. Dalam pengambilan keputusan penggunaan hutang ini harus mempertimbangkan besarnya biaya tetap yang muncul dari hutang berupa bunga menyebabkan semakin meningkatnya leverage keuangan dan semakin tidak pastinya tingkat pengembalian bagi para pemegang saham biasa. Kebijakan hutang adalah kebijakan yang diambil oleh pihak manajemen dalam rangka memperoleh sumber pembiayaan bagi perusahaan sehingga dapat digunakan untuk membiayai aktivitas operasional perusahaan. Selain itu kebijakan hutang perusahaan juga berfungsi sebagai alat monitoring terhadap tindakan manajer yang dilakukan dalam pengelolaan perusahaan.

Indahningrum (2013), Kebijakan hutang menggambarkan pengambilan keputusan manajemen dalam menetapkan sumber dana pihak ketiga untuk mendanai kegiatan perusahaan tersebut. Kebijakan hutang menjadi suatu kebijakan yang dipergunakan dalam menetapkan nilai pada sebuah perusahaan. Selain itu kebijakan hutang juga merupakan semua macam hutang yang diciptakan atau dibuat perusahaan, mulai dari hutang jangka panjang dan hutang jangka pendek, sedangkan menurut Mahsunah (2013), perusahaan yang memiliki tingkat kemampuan untuk memperoleh laba yang tinggi, maka hutang yang timbul akan berkurang dan mendahulukan dana dari dalam perusahaan untuk biaya investasi serta menghindari risiko keuangan. Perusahaan dengan pertumbuhan tingkat rendah yang memiliki tingkat kemampuan untuk memperoleh laba yang rendah menyebabkan penggunaan hutang untuk mendanai perusahaan akan meningkat. Kebijakan hutang diperjelas oleh Yeniatie dan Destriana (2010), bhawa kebijakan hutang didefinisikan sebagai jumlah hutang jangka panjang untuk mendanai operasional perusahaannya.

Munculnya akun hutang karena adanya pengorbanan aktifitas bisnis pada masa lalu untuk depan atas manfaat ekonomi yang muncul dari kewajiban saat ini entitas tertentu untuk mentranfer aktiva atau menyediakan jasa kepada entitas lainnya di masa depan sebagai hasil dari transaksi atau kejadian masa lalu, maka kebijakan hutang adalah kebijakan yang diambil oleh pihak manajemen dalam rangka memperoleh sumber pembiayaan bagi perusahaan sehingga dapat digunakan untuk membiayai aktivitas operasional perusahaan. Selain itu kebijakan hutang perusahaan juga berfungsi sebagai mekanisme monitoring terhadap tindakan manajer yang dilakukan dalam pengelolaan perusahaan.

Pengambilan keputusan kebijakan hutang, sebelumnya para manajer harus melalukan analisis dan mempertimbangkan besarnya biaya tetap yang akan muncul dari hutang berupa bunga yang akan menyebabkan semakin meningkatnya leverage keuangan dan semakin meningkatnya ketidak pastian pengembalian bagi para pemegang saham biasa 


\section{Free Cash Flow (FCF)}

Free cash flow merupakan kas perusahaan yang dapat didistribusikan kepada kreditur atau pemegang saham yang tidak diperlukan untuk modal kerja atau investasi pada aset. Kas tersebut biasanya menimbulkan konflik kepentingan antara manajer dan pemegang saham. Manajemen biasanya lebih suka untuk menginvestasikan lagi dana tersebut pada proyek-proyek yang dapat menghasilkan keuntungan, karena alternatif ini akan meningkatkan insentif yang diterimanya. Disisi lain, pemegang saham mengharapkan sisa dana tersebut.

Aliran kas bebas adalah cash flow yang tersedia untuk dibagikan kepada investor setelah perusahaan melakukan investasi pada fixed asset dan working capital yang diperlukan untuk mempertahankan kelangsungan usaha. Free cash flow merupakan kas perusahaan yang dapat didistribusikan kepada kreditur atau pemegang saham yang tidak diperlukan untuk modal kerja atau aset tetap (Tarjo, 2005 dalam Junaidi, 2012).

Pertemuan bisnis antara investor dan emiten di pasar modal akan mengharapkan terjadinya transaksi jual beli saham, kedua belah pihak memiliki perbedaan kepentingan yang berbeda, yakni yang memiliki dana (investor) dan yang membutuhkan dana (emiten). Bagi emiten, pasar modal salah satu alternatif untuk mendapatkan tambahan dana tanpa perlu menunggu hasil dari kegiatan operasional, sedangkan bagi investor pasar modal sebagai alternatif untuk melakukan investasi dan mendapatkan keuntungan yang optimal (Gian 2011).

Brigham dan Houston (2010), menjelaskan free cash flow memiliki perbedaan dengan cash flow bersih dalam beberapa hal yang penting. Free cash flow menggambarkan modal yang ada untuk semua investor, arus kas bersih menggambarkan modal yang ada untuk stakeholder biasa. Free cash flow juga menggambarkan modal yang ada untuk semua investor setelah mengurangi penanaman modal yang diperlukan untuk bias bertahan pada kegiatan perusahaan yang beroperasi. Free cash flow atau aliran kas bebas merupakan kas lebih perusahaan yang dapat didistribusikan kepada kreditor atau pemegang saham yang tidak diperlukan lagi untuk modal kerja atau investasi pada aset tetap

Arieska dan Gunawan (2011), Cash flow merupakan adanya dana berlebihan, yang semestinya dialokasikan pada pemegang saham Free cash flow menggambarkan kebebasan perusahaan untuk melakukan penanaman modal tambahan, menambah likuiditas, membeli saham dan melunasi hutang, kemudian ditegaskan teori free cash flow oleh Sonjaya (2015), Free cash flow merupakan kas berlebih pada perusahaan, yang dibutuhkan untuk mendanai semua kegiatan yang mempunyai net present value (NPV) positif sesudah dibagi deviden. Free Cash Flow to Firm adalah ukuran kinerja keuangan yang mengungkapkan jumlah arus kas bebas yang dihasilkan untuk perusahaan, yang terdiri dari biaya, pajak dan perubahan modal kerja bersih dan investasi

\section{Pengembangan Hipotesis}

\section{Market to Book Value of Assets terhadap Kebijakan Hutang dan Free Cash Flow}

Market to Book Value of Assets (MVA/BVA) sebagai proksi IOS yang pertama untuk mengukur rasio pertumbuhan modal. Rasio ini digunakan dengan dasar pemikiran bahwa semakin besar pertambahan modal yang dilakukan oleh perusahaan maka akan semakin tinggi investasi yang dilakukan perusahaan terhadap asset. MVA/BVA digunakan untuk mengukur prospek pertumbuhan perusahaan berdasarkan banyaknya asset yang digunakan dalam menjalankan usahanya dan bahan pertimbangan dalam penilaian kondisi perusahaan, 
Keuntungan yang diperoleh dari selisih nilai buku dan menjadi deviden setelah dikurangi dengan beban dan pajak. Dividen kas saat sekarang lebih berharga daripada kas masa depan yang diperoleh dari reinvestasi laba ditahan. Implikasinya bahwa investor lebih memerlukan pendapatan sekarang daripada pendapatan di masa mendatang dan selalu mencari sahamsaham yang membayar dividen secara tetap dan menawarkan dividend yield yang tinggi. Membayarkan dividen memberi sinyal dan keyakinan kepada investor bahwa reinvestasi pendapatan akan menghasilkan dividen yang lebih tinggi secara substansial dimasa mendatang. Perubahan dalam kebijakan dividen akan memengaruhi sikap investor pada perusahaan yang akan berakibat pada harga pasar, maka hipotesis yang dikembangkan adalah :

$\mathrm{H} 1$ : Market to Book Value of Assets (MVA/BVA) berpengaruh terhadap kebijakan hutang.

H6 : Market to Book Value of Assets (MVA/BVA) berpengaruh terhadap free cash flow

\section{Market to Book Value Equity terhadap kebijakan hutang dan Free Cash Flow}

Market to Book Value Equity (MVE/BVE) sebagai proksi kedua untuk menganalisis IOS. MVBE digunakan untuk menghitung nilai pasar terhadap nilai buku ekuitas yang mencerminkan adanya peluang investasi bagi suatu perusahaan berdasarkan harga dan permodalan suatu perusahaan. Penambahan modal dari penjualan saham kepada publik akan menambah nilai hutang saham tersebut dan hutang tersebut menjadi beban yang harus diselesaikan perusahaan hingga jatu tempo pembayaran, sebab hutang merupakan salah satu sumber pembiayaan yang bersumber dari luar perusahaan (eksternal) yang di gunakan oleh perusahaan sebagai penambahan dananya dalam menjalani perusahaannya.

Pengambilan keputusan kebijakan hutang, sebelumnya para manajer harus melalukan analisis dan mempertimbangkan besarnya biaya tetap yang akan muncul dari hutang berupa bunga yang akan menyebabkan semakin meningkatnya leverage keuangan dan semakin meningkatnya ketidak pastian pengembalian bagi para pemegang saham biasa, maka hipotesis yang dikembangkan dari uraian di atas adalah

H2: Market to Book Value Equity berpengaruh terhadap kebijakan hutang

H7 : Market to Book Value Equity berpengaruh terhadap free cash flow.

\section{Earning Per Share Price terhadap kebijakan hutang dan Free Cash Flow}

Earning Per Share Price (EPS) sebagai proksi ketiga IOS untuk mengitung keuntungan atau laba bersih yang diperoleh dari saham. Berdasarkan rasio EPS, investor dapat mengetahui keuntungan yang dihasilkan dari setiap lembar saham. Kesempatan investasi merupakan nilai perusahaan yang besarnya tergantung pada pengeluaran-pengeluaran yang telah di tetapkan manajemen dimasa yang akan datang dimana pada saat ini masih merupakan pilihan pilihan investasi yang diharapkan akan menghasilkan return yang lebih besar.

Menurut Tryfino (2009), EPS digunakan untuk memprediksi pergerakan harga saham, semakin besar EPS, maka kinerja perusahaan semakin baik. Hipotesis yang dikembangkan dari uraian di atas adalah

H3 : Earning Per Share Price berpengaruh terhadap kebijakan hutang.

H8 : Earning Per Share Price berpengaruh terhadap free cash flow 


\section{Capital Expenditure to Book Value Asset terhadap kebijakan hutang dan Free Cash Flow}

Capital Expenditure to Book Value Asset (CEP/BVA) sebagai proksi keempat IOS untuk mengukur nilai buku aset tetap dan jumlah nilai tambahan aset tetap yang mencerminkan adanya peluang investasi bagi suatu perusahaan melalui kesempatan adanya tambahan modal melalui nilai investasi riil berupa aset tetap. Perusahaan dengan IOS tinggi akan memiliki investasi yang tinggi. Selanjutnya ditemukan bahwa aktivitas investasi modal yang diukur dengan ratio capital expenditures to assets sebagai proksi IOS mempunyai hubungan positif dengan realisasi pertumbuhan (Wulansari 2013).

Ketika IOS tinggi penggunaan hutang perusahaan akan tetap rendah karena perusahaan akan lebih memilih untuk berinvestasi daripada menggunakan hutang. Namun pada saat IOS rendah perusahaan akan menggunakan tingkat hutang yang tinggi. Semakin tinggi tingkat pengawasan oleh pihak institusional akan semakin rendah penggunaan hutang perusahaan oleh manajer karena perusahaan akan lebih cenderung mengambil kesempatan untuk berinvestasi untuk mendapatkan keuntungan.

Rasio CEP/BVA digunakan dengan dasar pemikiran bahwa semakin besar pertambahan modal yang dilakukan oleh perusahaan maka akan semakin tinggi kadar investasi yang dilakukan perusahaan dari mengukur kinerja harga pasar saham terhadap nilai bukunya yang menunjukkan aktiva bersih yang dimiliki oleh pemilik saham dengan memiliki satu lembar saham. Hipotesis yang dikembangkan dari CEP/BVA adalah

H4: Capital Expenditure to Book Value Asset berpengaruh terhadap kebijakan hutang.

$\mathrm{H} 9$ : Capital Expenditure to Book Value Asset berpengaruh terhadap free cash flow

\section{Capital Expenditure to Market Value of Assets terhadap kebijakan hutang dan Free Cash Flow}

Capital Expenditure to Market Value of Assets menjadi proksi IOS yang kelima digunakan untuk mengukur kinerja harga pasar saham terhadap nilai bukunya. Perusahaan mempunyai berbagai macam usaha dalam menarik jumlah investor dan meningkatkan harga sahamnya, salah satunya yaitu meningktakan kinerja.

Investment opportunity sebagi perusahaan sudah cukup serta berfungsi untuk meningkatkan produktivitas perusahaan, karena sumber dana perusahaan dapat dicukupi dengan besarnya investment opportunity set yang dilakukan perusahaan, sehingga dengan menggunakan sumber pendanaan internal untuk kegiatan operasional perusahaan lebih menguntungkan. Dengan adanya Investment Opportunity Set yang tinggi maka perusahaan akan lebih memilih untuk berinvestasi dikarenakan semakin besarnya perusahaan maka semakin banyak suatu perussahaan membutuhkan dana sehingga perusahaan membutuhkan kesempatan investasi yang tinggi untuk mendapatkan dana yang lebih besar dikemudian hari. Semakin tinggi IOS maka perusahaan akan mengambil kebijakan berinvestasi daripada mengambil hutang.

Nilai buku lembar saham menunjukkan aktiva bersih yang dimiliki oleh pemilik saham dengan memiliki satu lembar saham. Rasio CEP/MVA ini digunakan dengan dasar pemikiran bahwa semakin besar investasi yang dilakukan oleh perusahaan pada aset tetap maka akan semakin tinggi kadar investasi yang dilakukan perusahaan dari perbandingan antara perubahan modal dengan harga pasar perusahaan. Hipotesis yang dikembangkan dari uraian di atas adalah H5 : Capital Expenditure to Market Value of Assets berpengaruh terhadap kebijakan hutang. H10 : Capital Expenditure to Market Value of Assets berpengaruh terhadap free cash flow 


\section{METODOLOGI PENELITIAN}

\section{Jenis dan Sumber Data Penelitian}

Jenis data yang digunakan dalam penelitian ini adalah data sekunder, yaitu data-data yang disediakan oleh pihak lain dan tidak berasal dari sumber langsung. Data yang diperoleh berupa laporan keuangan perusahaan manufaktur yang dipublikasikan oleh Bursa Efek Indonesia (BEI) tahun 2016 - 2017. Populasi yang digunakan dalam penelitian ini adalah semua perusahaan manufaktur yang terdaftar di Bursa Efek Jakarta (BEJ). Pengambilan sampel dilakukan dengan metode purposive sampling. Jumlah populasi 168 yang memenuhi kriteria sebanyak 40 perusahaan, maka data penelitian $40 \times 2$ tahun yaitu 80 data

\section{Metode Analisis dan Hipotesisi Penelitian}

Pengujuan pertama pendekatan SEM Tools AMOS dan SPSS untuk menguji statistik deskriptif, Kemudian pengujian asumsi klasik sebagai salah satu syarat untuk bisa menggunakan persamaan regresi berganda adalah terpenuhinya uji asumsi klasik. Empat uji asumsi klasik dalam penelitian ini meliputi normalitas, asumsi heteroskedastisitas, autokorelasi dan multikolinearitas. Penjelasan masing-masing pengujian asumsi klasik akan diuraikan seperti di bawah ini. Lanjutan pengujian untuk metode analisis yang digunakan untuk menguji pengaruh variabel bebas terhadap terikat dengan Uji T, Uji F dan Uji Determinasi

\section{Operasional Variabel Penelitian}

Investment opportunity set menjadi variable bebas untuk menganalisis luasnya kesempatan peluang investasi bagi perusahaan Pengukuran investment opportunity set melalui beberapa alternatif proksi gabungan IOS dilakukan sebagai upaya untuk mengurangi kesalahan pengukuran yang ada pada proksi dengan rasio individual, sehingga akan menghasilkan pengukuran yang baik Proksi IOS berbasis pada harga (Price - Based Proxies) : Market to Book Value of Assets (MVA/BVA), Market to Book Value Equity (MVE/BVE), Earning Per Share Price (EPS) dan Proksi IOS berbasis pada investasi (Investment - Based Proxies) : Capital expenditure to Book Value Asset (CEP/BVA), Capital Expenditure to Market Value of Assets (CEP/MVA). Proksi pertama IOS dari Market to Book Value of Assets (MVA/BVA).

a. Market to Book Value of Assets Ratio (MVA/BVA)

Proksi ini dihitung untuk menunjukkan prospek pertumbuhan perusahaan yang dinyatakan dalam harga pasar. Rasio ini menjelaskan gabungan antara aset di tempat dengan kesempatan investasi. Oleh karena itu, semakin tinggi rasio MVA/BVA, semakin tinggi kesempatan investasi yang dimiliki perusahaan tersebut yang berkaitan dengan aset di tempat. Rumus menghitung rasio Market to Book Value of Assets Indah (2011), Terestiani (2011), Pratania (2011) dan Manik, Tumpal (2014) sebagai berikut :

$$
\begin{aligned}
& \text { MVA/BVA }=\frac{(\text { TA }- \text { TE })+(C S \times C P)}{\text { Total Assets }} \times 100 \% \\
& \text { Keterangan MVA : Market Value of Assets Ratio TE : Total Equty } \\
& \text { BVA : Book Value of Assets Ratio CS : Saham beredar } \\
& \text { TA : Total Assets HPS : Harga Penutupan Saham }
\end{aligned}
$$

b. Market to Book Value Equity Ratio (MVE/BVE)

Menunjukkan peluang investasi perusahaan, apabila perusahaan dapat memanfaatkan modalnya dengan baik, maka semakin besar kemungkinan perusahaan tersebut untuk bertumbuh dan mencerminkan bahwa pasar menilai return atas investasi perusahaan pada 
masa depan akan lebih besar dari return yang diharapkan ekuitasnya.Terestiani (2011), Pratania (2011) dan Manik, Tumpal (2014) sebagai berikut :

$$
\text { MVE/BVE }=\frac{\text { Saham Beredar } x \text { Harga Penutupan }}{\text { Total Ekuitas }} \times 100 \%
$$

c. Earning per Share Price Ratio (EPS)

Earning per Share Price Ratio (EPS), menggambarkan seberapa besar earning power yang dimiliki perusahaan. Perhutungan Earning per Share Price Ratio dengan laba per lembar saham diperoleh dari laba bersih perusahaan dibagi dengan jumlah lembar saham yang beredar, sedangkan nilai harga saham diperloeh dari harga penutupan saham akhir tahun. Terestiani (2011), Pratania (2011) dan Manik, Tumpal (2014) sebagai berikut:

$$
\text { EPS }=\frac{\text { Laba Perlembar Saham }}{\text { Harga Penutupan }} \times 100 \%
$$

d. Capital Expenditure to Book Value Asset Ratio (CEA/BVA),

Rasio ini digunakan dengan dasar pemikiran bahwa semakin besar investasi yang dilakukan oleh perusahaan pada aset tetap maka akan semakin tinggi kadar investasi yang ilakukan perusahaan dan menunjukkan produktivitas investasi yang tercermin dari total assets perusahaan. Rasio CEA/BVA dapat Pratania (2011) dan Manik, Tumpal (2014) sebagai berikut :

$$
\text { CEA/BVA }=\frac{\text { Nilai BukuAset Tetap }}{\mathrm{t} \text { NilaiBukuAset Tetap } \mathrm{t}_{\mathrm{t}}-1} \times 100 \%
$$

e. Capital Expenditure to Market Value of Assets Ratio (CEA/MVA)

Menunjukkan perbandingan antara perubahan modal dengan harga pasar perusahaan. Rasio ini digunakan dengan dasar pemikiran bahwa semakin besar investasi yang dilakukan oleh perusahaan pada aset tetap maka akan semakin tinggi kadar investasi yang dilakukan perusahaan. Rasio CEA/MVA mengacu pada penelitian, Terestiani (2011), Pratania (2011) dan Manik, Tumpal (2014) sebagai berikut :

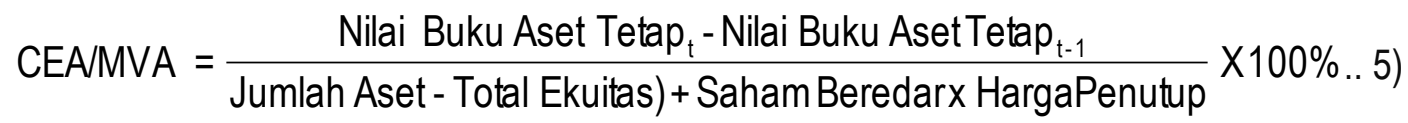

\section{Kebijakan Hutang}

Kebijakan hutang adalah aktivitas manajemen yang digunakan untuk membiayai operasional dengan penggunaan modal yang asalnya dari hutang. Rumus kebijakan hutang sebagai berikut (Tarjo, 2005):

KebijakanHutang $=\frac{\text { Total Hutang }}{\text { Total Ekuitas }}$

\section{Free Cash Flow (FCF)}

Free cash flow (FCF) yaitu cash berlebih sebuah perusahaan yang bisa dialokasikan pada creditors maupun stakeholder yang tidak dibutuhkan untuk penenaman modal pada modal kerja.Perhitungan free cash flow menggunakan rumus sebagai berikut (Mahsunah dan Hermanto, 2013) :

$$
\mathrm{FCF}=\frac{\mathrm{AKO}_{\mathrm{it}}-\mathrm{PM}_{\mathrm{it}}-\mathrm{NWC}_{\mathrm{it}}}{\text { Total Aset }}
$$




\section{HASIL DAN PEMBAHASAN}

\section{Hasil Analisis Parth Diagram}

Pengujian parth diagram menggunakan SEM Tools AMOS menunjukkan hasil penelitian yang memiliki hubungan yang positip antara variabel indenpenden dengan variabel bebas. Hasil pengujian analisis parth diagram diuraikan dalam tabel 1. Hasil pengujian Goodness of Fit (GOF) dan output path diagram Faktor-Faktor Yang Mempengaruhi Investment Opportunity Set terhadap Kebijakan Hutang Dan Free Cash Flow berdasarkan nilai C.R. (critical ratio) nilai CR > 1,96 dan nilai $P<0,05$, dan evaluasi telah memenuhi kriteria goodness of fit Model SEM Tools Amos. Hasil pengujian hipotesis ditunjukkan pada tabel dibawah ini.

Tabel. 1 Hasil Estimasi Parameter dan Standard Error

Faktor-Faktor Yang Mempengaruhi Investment Opportunity Set terhadap Kebijakan Hutang dan Free Cash Flow

\begin{tabular}{llrrrrl}
\hline & & Estimate & S.E. & C.R. & P & Label \\
\hline KU <--- & MVE_BVE &, 182 &, 017 & 10,987 & $* * *$ & Signifikan \\
KU <-- & CEA_MVA &, 150 &, 016 & 9,220 & $* * *$ & Signifikan \\
KU <--- & MVA_BVA &, 161 &, 017 & 9,247 & $* * *$ & Signifikan \\
KU <--- EPS &, 191 &, 019 & 10,060 & $* * *$ & Signifikan \\
KU <-- & CEA_BVA &, 176 &, 015 & 11,680 & $* * *$ & Signifikan \\
\hline FCF <--- & CEA_MVA &,- 324 &, 069 & $-4,728$ & $* * *$ & Signifikan \\
FCF <--- & MVA_BVA &,- 438 &, 073 & $-5,990$ & $* * *$ & Signifikan \\
FCF <--- & MVE_BVE &,- 422 &, 074 & $-5,684$ & $* * *$ & Signifikan \\
FCF <--- CEA_BVA &,- 577 &, 069 & $-8,354$ & $* * *$ & Signifikan \\
FCF <--- EPS &,- 085 &, 082 & $-1,031$ &, 303 & Tidak Sig \\
FCF <--- KU & 3,148 &, 258 & 12,184 & $* * *$ & Signifikan \\
\hline
\end{tabular}

Faktor-Faktor Yang Mempengaruhi IOS terhadap Kebijakan Hutang

Hasil pengolahan data SPSS menunjukkan semua variabel secara parsial berpengaruh signifikan terhadap Free cash flow, ditunjukkan dalam tabel dibawah ini;

Tabel. 1. Hasil Uji Hipotesis Penelitian Jalur I (Pertama)

\begin{tabular}{|c|c|c|c|c|}
\hline \multicolumn{4}{|l|}{ Keterangan } & Nilai \\
\hline \multicolumn{4}{|l|}{ R Square } & 0.892 \\
\hline \multicolumn{4}{|c|}{ Adjusted R Square } & 0.889 \\
\hline \multicolumn{4}{|c|}{ F hitung } & 287.472 \\
\hline \multicolumn{4}{|l|}{ Probabilitas } & 0,000 \\
\hline Keterangan & $\begin{array}{l}\text { Unstandardized } \\
\text { Coefficients }\end{array}$ & $\begin{array}{c}\text { Standardized } \\
\text { Coefficients }\end{array}$ & Uji-T & $\begin{array}{l}\text { Probabilitas } \\
\text { (Sig. a } 0,05)\end{array}$ \\
\hline Constant & 3,080 & & 5,222 & 0,000 \\
\hline MVA_BVA & 0,161 & 0,256 & 9,117 & 0,000 \\
\hline MVE_BVE & 0,182 & 0,292 & 10,833 & 0,000 \\
\hline EPS & 0,191 & 0,327 & $9 ., 918$ & 0,000 \\
\hline CEA_BVA & 0,176 & 0,317 & 11,516 & 0,000 \\
\hline CEA_MVA & 0,150 & 0,301 & 9,090 & 0,000 \\
\hline
\end{tabular}

a. Dependent Variable: KU

b. Predictors: (Constant), CEA_MVA, MVA_BVA, MVE_BVE, CEA_BVA, EPS Output SPSS V.24, (2018) 
Hasil pengujian hipotesis jalur I (Pertama) secara bersamaan (simultan) variabel, bahwa

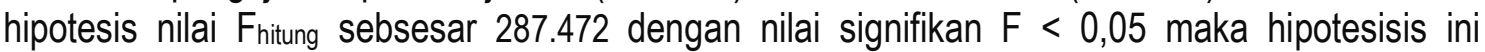
membuktkan bahwa faktor-faktor yang mempengaruhi investment opportunity set terhadap kebijakan tidak dapat ditolak berpengaruh signifikan dengan model persamaan regresi berganda diformulasikan sebagai berikut :

$$
\begin{aligned}
\mathrm{KU}= & 3,080+0,161 \mathrm{MVA} \text { _BVA }+0,182 \mathrm{MVE} \_\mathrm{BVE}+0,191 \mathrm{EPS}+0,176 \text { CEA_BVA } \\
& +0,150 \text { CEA_MVA }+\varepsilon
\end{aligned}
$$

Hasil output Uji Parsial (Uji T) Investment opportunity set menunjukkan pengaruh signifikan terhadap kebijakan hutang, antara lain :

H1: Market to Book Value of Assets Ratio (MVA/BVA) berpengaruh signifikan terhadap kebijakan hutang sebesar $16,1 \%$, artinya menunjukkan prospek pertumbuhan perusahaan yang dinyatakan dalam harga pasar bahwa MVA/BVA menjelaskan gabungan antara aset di tempat dengan kesempatan investasi. Oleh karena itu, semakin tinggi rasio MVA/BVA, semakin tinggi kesempatan investasi yang dimiliki perusahaan tersebut yang berkaitan dengan kebijakan hutang di tempat.

$\mathrm{H} 2$ : Market to Book Value Equity Ratio (MVE/BVE) berpengaruh signifikan terhadap kebijakan hutang sebesar $18,2 \%$, apabila perusahaan dapat memanfaatkan modalnya dengan baik, maka semakin besar kemungkinan perusahaan tersebut untuk bertumbuh dan mencerminkan bahwa pasar menilai return atas investasi perusahaan pada masa depan akan lebih besar dari return

H3 : Earning per Share Price Ratio (EPS) berpengaruh signifikan terhadap kebijakan hutang sebesar 19,1\%, artinya menggambarkan semakin besar earning power yang dimiliki perusahaan degan laba per lembar saham diperoleh dari laba bersih perusaha, maka semakin besar juga kebijakan hutang dari kenaikn nilai harga saham diperloeh dari dari harga penutupan saham akhir tahun.

H4: Capital Expenditure to Book Value Asset Ratio (CEA/BVA) berpengaruh signifikan terhadap kebijakan hutang sebesar $17,6 \%$, artinya semakin besar investasi yang dilakukan oleh perusahaan pada aset tetap maka akan semakin tinggi kadar investasi yang dilakukan perusahaan dan menunjukkan produktivitas investasi yang tercermin dari total assets perusahaan yang diperoleh dari kebijakan hutang.

H5 : Capital Expenditure to Market Value of Assets Ratio (CEA/MVA) berpengaruh signifikan terhadap kebijakan hutang sebesar 15\%, artinya perbandingan antara perubahan modal dengan harga pasar perusahaan. CEA/MVA digunakan semakin besar investasi yang dilakukan oleh perusahaan pada aset tetap maka akan semakin tinggi kebijakan hutang yang dilakukan perusahaan.

\section{Faktor-Faktor Yang Mempengaruhi IOS terhadap Kebijakan Hutang}

Hasil pengolahan data SPSS menunjukkan semua variabel IOS secara parsial berpengaruh signifikan terhadap Kebijakan Hutang dan Free cash flow. Hasil pengujian hipotesis jalur II (Kedua) secara bersamaan (simultan) variable (tabel 2), bahwa hipotesis nilai $F_{\text {hitung }}$ sebsesar 55,799 sedangkan nilai signifikan F-nya adalah sebesar 0,000 yang dan nilai signifikan $\mathrm{F}<0,05$, artinya hipotesisis menunjukkan bahwa faktor-faktor yang mempengaruhi Investment Opportunity Set terhadap Kebijakan Hutang dan Free cash flow tidak dapat ditolak berpengaruh signifikan dengan model persamaan regresi berganda diformulasikan sebagai berikut :

$$
\begin{aligned}
\mathrm{KU}= & 3,080-6,062 \mathrm{MVA} \text { _BVA }-0,438 \mathrm{MVE} \_B V E-0,422 \mathrm{EPS}-0,085 \text { CEA_BVA } \\
& -0,577 \text { CEA_MVA }-0,324 \mathrm{KU}+\varepsilon
\end{aligned}
$$


Faktor-Faktor Yang Mempengaruhi Investment Opportunity Set

Terhadap Kebijakan Hutang Dan Free Cash Flow

Tabel. 2. Hasil Uji Hipotesis Penelitian Jalur II (Kedua)

\begin{tabular}{|c|c|c|c|c|}
\hline \multicolumn{4}{|l|}{ Keterangan } & Nilai \\
\hline \multicolumn{4}{|l|}{ R Square } & 0,659 \\
\hline \multicolumn{4}{|c|}{ Adjusted R Square } & 0,647 \\
\hline \multicolumn{4}{|c|}{ F hitung } & 55,799 \\
\hline \multicolumn{3}{|l|}{ Probabilitas } & & 0,000 \\
\hline Keterangan & $\begin{array}{l}\text { Unstandardized } \\
\text { Coefficients }\end{array}$ & $\begin{array}{c}\text { Standardized } \\
\text { Coefficients }\end{array}$ & Uji-T & $\begin{array}{l}\text { Probabilitas } \\
\text { (Sig. a } 0,05)\end{array}$ \\
\hline Constant & 3,080 & & $-2,756$ & 0,006 \\
\hline MVA_BVA & $-0,602$ & $-0,358$ & $-5,889$ & 0,000 \\
\hline MVE_BVE & $-0,438$ & $-0,348$ & $-5,588$ & 0,000 \\
\hline EPS & $-0,422$ & $-0,074$ & $-1,014$ & 0,312 \\
\hline CEA_BVA & $-0,085$ & $-0,535$ & $-8,213$ & 0,000 \\
\hline CEA_MVA & $-0,577$ & $-0,333$ & $-4,648$ & 0,000 \\
\hline $\mathrm{KH}$ & $-0,324$ & 1.618 & 11,978 & 0,000 \\
\hline
\end{tabular}

a. Dependent Variable : FCF

b. Predictors: (Constant), KH, MVA_BVA, MVE_BVE, CEA_BVA, CEA_MVA, EPS

Output SPSS V.24, (2018)

Hasil output Uji Parsial (Uji T) Kebijakan Hutang dan Free cash flow menunjukkan pengaruh signifikan dan tidak signifikan terhadap kebijakan hutang, antara lain :

H6: Market to Book Value of Assets Ratio (MVA/BVA) berpengaruh signifikan terhadap Free cash flow sebesar $-60,2 \%$, artinya menunjukkan prospek pertumbuhan perusahaan yang dinyatakan dalam harga pasar bahwa MVA/BVA menjelaskan gabungan antara aset di tempat dengan kesempatan investasi. Oleh karena itu, semakin rendah rasio MVA/BVA, maka semakin rendah kesempatan investasi yang dimiliki perusahaan tersebut yang berkaitan dengan free cash flow di tempat.

H7 : Market to Book Value Equity Ratio (MVE/BVE) berpengaruh signifikan terhadap free cash flow sebesar $-43,8 \%$, apabila perusahaan dapat memanfaatkan modalnya tidak baik, maka semakin rendah menilai return atas investasi perusahaan pada masa depan akan lebih kecil dari return

H8: Earning per Share Price Ratio (EPS) tidak berpengaruh signifikan terhadap free cash flow.

H9: Capital Expenditure to Book Value Asset Ratio (CEA/BVA) berpengaruh signifikan terhadap free cash flow sebesar $-8,5 \%$, artinya semakin rendah investasi yang dilakukan oleh perusahaan pada aset tetap maka akan semakin rendah kadar investasi yang dilakukan perusahaan dan menunjukkan produktivitas investasi yang tercermin dari total assets perusahaan yang diperoleh dari free cash flow.

H10 : Capital Expenditure to Market Value of Assets Ratio (CEA/MVA) berpengaruh signifikan terhadap free cash flow sebesar $-57,7 \%$, artinya perbandingan antara perubahan modal dengan harga pasar perusahaan semakin rendah. CEA/MVA digunakan semakin kecil investasi yang dilakukan oleh perusahaan pada aset tetap maka akan semakin berkurang kebijakan hutang yang dilakukan perusahaan. 


\section{REKOMENDASI DAN KEBIJAKAN}

\section{Rekomendasi}

Berdasarkan hasil pengujian sesuai dengan tujuan penelitian ini, maka rekomendasi hasil penelitian ini antara lain :

1. Faktor-Faktor Yang Mempengaruhi Investment Opportunity Set Terhadap Kebijakan Hutang Berpengaruh singnifikan, antara lain proksi IOS berdasarkan Market to Book Value of Assets Ratio (MVA/BVA) berpengaruh signifikan terhadap kebijakan hutang sebesar 16,1\%, Market to Book Value Equity Ratio (MVE/BVE) berpengaruh signifikan terhadap kebijakan hutang sebesar $18,2 \%$, Earning per Share Price Ratio (EPS) berpengaruh signifikan terhadap kebijakan hutang sebesar 19,1\%, Capital Expenditure to Book Value Asset Ratio (CEA/BVA) berpengaruh signifikan terhadap kebijakan hutang sebesar 17,6\%, Capital Expenditure to Market Value of Assets Ratio (CEA/MVA) berpengaruh signifikan terhadap kebijakan hutang sebesar $15 \%$.

2. Faktor-faktor yang mempengaruhi investment opportunity set terhadap free cash flow, antara lain proksi IOS berdasarkan Market to Book Value of Assets Ratio (MVA/BVA) berpengaruh signifikan terhadap Free cash flow sebesar -60,2\%, Market to Book Value Equity Ratio (MVE/BVE) berpengaruh signifikan terhadap free cash flow sebesar $-43,8 \%$, Earning per Share Price Ratio (EPS) tidak berpengaruh signifikan terhadap free cash flow, Capital Expenditure to Book Value Asset Ratio (CEA/BVA) berpengaruh signifikan terhadap free cash flow sebesar $-8,5 \%$, Capital Expenditure to Market Value of Assets Ratio (CEA/MVA) berpengaruh signifikan terhadap free cash flow sebesar $-57,7 \%$,

\section{Kebijakan}

Bedasarkan hasil dan interpretasi penelitian ini, maka peneliti memberikan saran sebagai rekomendasi kebijakan antara lain : 1) Faktor-Faktor Yang Mempengaruhi Investment Opportunity Set dapat diprosikan dengan rasio individual, sehingga akan menghasilkan pengukuran yang baik Proksi IOS berbasis Market to Book Value of Assets (MVA/BVA), Market to Book Value Equity (MVE/BVE), Earning Per Share Price (EPS) dan Proksi IOS berbasis pada investasi (Investment - Based Proxies) : Capital expenditure to Book Value Asset (CEP/BVA), Capital Expenditure to Market Value of Assets (CEP/MVA). Proksi pertama IOS dari Market to Book Value of Assets (MVA/BVA). 2) Penelitian ini dapat dilanjutka dengan variabel penelitia lannnya yang berhubungan dengan faktor-faktor yang mempengaruhi investment opportunity set

\section{DAFTAR PUSTAKA}

Aharony, J., J. W. Wang, dan H. Q. Yuan. 2010. Tunneling as an incentive for earnings management during the IPO process in China. Journal of Accounting and Public Policy. Vol.29: 1-26

Arieska, M dan Gunawan, B. 2011. "Pengaruh Aliran Kas Bebas dan Keputusan Pendanaan terhadap Nilai Pemegang Saham dengan Set Kesempatan Investasi Deviden sebagai Variabel Moderasi". Jurnal Akuntansi dan Keuangan, Vol. 13, No. 1, Hal. 13 - 23

Brigham, E. F. dan J. F. Houston. 2010. Fundamental of Financial Management Edisi Kesepuluh. Buku 1. South - Weastern. Singapore. Terjemahan A.A Yulianto. 2012. Dasar - dasar Managemen Keuangan. Edisi Kesepuluh. Buku 1. Jakarta: Salemba Empat.

Indah, Khairunnisa Ningrum (2011), Analisis Pengaruh Investment Opportunity Set (IOS) Terhadap Return Saham Perusahaan (Studi Pada Perusahaan Yang Terdaftar di Bursa Efek 
Indonesia Tahun 2005-2009) Jurusan Manajemen Fakultas Ekonomi Universitas Sebelas Maret Surakarta.

Indah ningrum dan Handayani. 2013. Pengaruh Kepemilikan Manajerial, Kepemilikan Institusional, Deviden, Pertumbuhan Perusahaan, Free Cash Flow, dan Profitabilitas terhadap Kebijakan Hutang Perusahaan". Jurnal Bisnis dan Akuntansi, Vol. 11, No. 3, Hal. $189-207$.

Manik, Tumpal. 2014. Analisis Pengaruh Struktur Modal dan Investment Opportunity Set (IOS)

Terhadap Keputusan Investasi Dan Harga Saham Melalui Analisis Jalur. Prosiding Seminar Nasional dan Call For Papers Business in Society :Towards Asian Era Fakultas Ekonomi dan Bisnis Universitas Sebelas Maret Surakarta.

Mahsunah, T. dan Hermanto, S.B. 2013. "Pengaruh free Cash Flow, Profitabilitas dan KepemilikanInstitusional terhadap Kebijakan Hutang". Jurnal Ilmu \& Riset AkuntansiVol. 2, No. 12, Hal. 1 - 19.

Sonjaya, Y. 2015. "Analisis Pengaruh Free Cash Flow, Kebijakan Deviden, Kepemilikan Saham Manajerial, dan Kepemilikan Saham Institusional terhadap Nilai Perusahaan". Jurnal IImu dan Riset Akuntansi.

Suartawan dan Yasa. 2015. Pengaruh Investment Opportunity Set Dan Free Cash Flow Pada Kebijakan Dividen Dan Nilai Perusahaan. Jurnal. Universitas Udayana Bali.

Terestiani, Putu Dadri. 2011. Pengaruh Investment Opportunity Set Dan Struktur Modal Terhadap Return Saham Pada Perusahaan Farmasi Di Bursa Efek Indonesia. Program Magister Program Pascasarjana Universitas Udayana Denpasar.

Yeniatie dan Destriana, N. 2010. "Faktor-Faktor yang Mempengaruhi Kebijakan Hutang pada Perusahaan Nonkeuangan yang Terdaftar di Bursa Efek Indonesia". Jurnal Bisnis dan Akuntansi, Vol. 12, No. 1, Hal. 1- 16. 